Original Article

http://dx.doi.org/10.1590/0104-07072014002010013

\title{
INTERPERSONAL RELATIONSHIPS AMONG HOSPITAL NURSES AND THE USE OF COMMUNICATION SKILLS
}

\author{
Yolanda Raquel Lapeña Moñux¹, Luis Cibanal Juan², Azucena Pedraz Marcos ${ }^{3}$, María Loreto Macía Soler
}

\footnotetext{
${ }^{1}$ Doctor of Health Sciences. Assistant Professor of the Predepartmental Nursing Unit, Health Science College, Universidad Jaime I de Castellón de la Plana. Castellón, Spain. E-mail: ylapena@uji.es

2 Professor of Nursing. Department of Nursing, Universidad de Alicante. Alicante, Spain. E-mail: luis.cibanal@ua.es

${ }^{3}$ Doctor and Professor of Nursing. Department of Surgery, Autonomous Universidad de Madrid. Madrid, Spain. E-mail: azucena. pedraz@uam.es

${ }^{4}$ Vice Dean of the College of Health Sciences, Universidad Jaime I de Castellón de la Plana. Castellón, Spain. E-mail: macia@uji.es
}

\begin{abstract}
A qualitative exploratory and descriptive study investigating how the work relationships of nursing professionals are affected by the organizational problems experienced in hospital units and their management. Participants consisted of 21 nurses who worked in a general hospital in the north of Spain, during the period between 2010 and 2012. The study was approved by an ethics research committee and participants signed an informed consent form. Data were collected through in-depth interviews and field records. Using thematic analysis, the results displayed that work disorganization affects interpersonal relationships, generating feelings of impotence and demotivation among participants. Thus, they considered it necessary for a work plan to be established, clearly defining the activities of each professional role and developing the necessary communication skills for expressing problems to managers and coworkers. We believe it would be of great benefit for managers to take into consideration the suggestions for improvement presented in this study.
\end{abstract}

DESCRIPTORS: Labor relations. Hospital administration. Nursing staff.

\section{LAS RELACIONES INTERPERSONALES DE LOS ENFERMEROS EN ASISTENCIA HOSPITALARIA Y EL USO DE HABILIDADES COMUNICATIVAS}

RESUMEN: Estudio exploratorio-descriptivo, cualitativo, para conocer cómo afectan a las relaciones laborales de los profesionales de enfermería los problemas organizativos vividos en las unidades hospitalarias y la forma de gestionarlos. Los participantes fueron 21 enfermeros que trabajaban en un hospital general del norte de España, en el periodo de 2010-2012, con la aprobación del comité ético y de investigación y la firma del consentimiento informado. Los datos se recolectaron mediante entrevistas en profundidad y diario de campo. A partir del análisis temático, los resultados mostraron que la desorganización del trabajo afecta a las relaciones interpersonales, generando en los participantes sentimientos de impotencia y desmotivación. Por ello, consideran necesario realizar una planificación del trabajo, clarificar las actividades de cada rol profesional y desarrollar las habilidades comunicativas necesarias para transmitir los problemas a gestores y compañeros. Se estima conveniente que los gestores tuvieran en consideración las propuestas de mejora señaladas en el estudio.

DESCRIPTORES: Relaciones laborales. Administración hospitalaria. Personal de enfermería.

\section{AS RELAÇÕES INTERPESSOAIS DOS ENFERMEIROS NA ASSISTÊNCIA HOSPITALAR E O USO DAS CAPACIDADES COMUNICATIVAS}

RESUMO: Estudo exploratório-descritivo, qualitativo, para conhecer os problemas organizativos que ocorreram nas unidades hospitalares e a maneira de os gerir nas relações laborais dos profissionais da enfermagem. Os participantes foram 21 enfermeiros que trabalhavam num hospital geral do Norte da Espanha, entre os anos 2010 e 2012. Os dados foram obtidos por meio de entrevistas em profundidade e de diário de campo. A partir da análise temática, os resultados mostraram que a desorganização no trabalho afeta as relações interpessoais, criando nos participantes sentimento de impotência e desmotivação. Por este motivo, consideram necessário realizar uma planificação do trabalho, esclarecer as atividades de cada profissional e desenvolver as capacidades comunicativas necessárias para transmitir os problemas aos gestores e aos colegas de trabalho.

DESCRITORES: Relações trabalhistas. Administração hospitalar. Recursos humanos de enfermagem. 


\section{INTRODUCTION}

Nowadays, it has become ever more common to observe problems regarding labor dissatisfaction among hospital nursing staff. These are due in part to problems with labor organization ${ }^{1}$ in the hospital units and how such problems are managed. This dissatisfaction is also due to relationship problems and the absence of adequate communication, which encompasses active listening, empathy and authenticity. ${ }^{2}$ These skills would help express problems effectively and thus improve the working lives of professionals who work in hospitals every day. Communication between nurses and coworkers, in conjunction with good interpersonal relationships and social interaction are considered indispensable conditions for feeling comfortable with one's work. ${ }^{3}$

In light of this, managers must value the need for creating work environments which prioritize social support for professionals ${ }^{4}$ (development and training opportunities), for such actions improve job performance and reduce stress levels. ${ }^{5-6}$ It is also necessary for managers to develop organizational formulas suggested by workers with the goal of reducing precarious working conditions. ${ }^{7}$

The proper use of relationship attitudes and skills would help nursing professionals to express these problems to the institutions, to seek solutions among peers, improve job satisfaction and reduce their experience of occupational stress. ${ }^{8} \mathrm{It}$ also facilitates and leads nursing professionals to have expectations of self-efficacy and coping styles that allow them to defend themselves from actions that threaten their sense of self. ${ }^{9}$

It is important to recognize that most nurses know and were trained in certain relationship skills, such as empathy. ${ }^{10}$ Nonetheless, we observe that it is challenging for them to use such knowledge when communicating with managers about the organizational problems of their work and ultimately improving their work life. In order to improve job satisfaction, it is necessary to overcome these communication barriers. ${ }^{11}$ For this reason, some authors present the need for developing training programs for dealing with occupational difficulties and reducing communication problems. ${ }^{12-13}$

On the other hand, the lack of order in the work place translates into a poor working environment that greatly affects the development of amicable work relatioships ${ }^{14}$ and leads to work overload that reverts to demotivation ${ }^{8}$ and lack of initiative on behalf of the professionals for reaching the goals set forth by the institution. It is important to watch over the staff's work in order to guarantee its functioning and create work spaces that provide a favorable psychological climate of safety, trust, positivity and empathy among all. In such a space, administrators can communicate more effectively with workers ${ }^{4}$, paving the way for amicable work relationships. Thus, it becomes easier and more comfortable for the staff to express organizational problems with the goal of improving coexistence and job satisfaction.

Improper interpersonal communication leads to negative repercussions for the patient as well as for professionals. Despite being aware of these facts, we find that most nurses have a difficult time expressing shortcomings so that they can develop effective communicative relationships and strategies for solving communication problems.

It is for this reason that, ultimately, we would like this study to contribute, on the one hand, to stimulating healthcare professionals to recognize the need for communicating organizational problems through the proper use of relationship skills. This would allow them to achieve higher job satisfaction and decrease interpersonal conflict. On the other hand, we hope this study can help the institution apply the best suggestions for improving clinical care practice.

Therefore, through this study will allow us to learn the communication-relationship problems encountered by our participants when expressing organizational problems and develop strategies for improving them. Attention must always be given to effective communication, but it is especially relevant in strongly emotionally-charged situations, ${ }^{15}$ as is the case of work conflicts due to poor work organization. Thus, in order to improve the nurse's work, personal and family life, it is important that these problems be communicated with adequate communication skills.

Based on the above, the objective of the present study is to explore how work relationships are affected by the organizational problems experienced in different hospital services and how they are managed.

\section{METHODOLOGY}

This is an exploratory-descriptive study of qualitative approach, ${ }^{16-17}$ based on the theoretical framework of the communication-relationship theory. ${ }^{2}$ It was conducted in the different inpatient 
units of a general hospital in the North of Spain between the period of October 2010 and February 2012 (period comprising the preparation of field work until the production of the first results). The hospital contained 250 beds and its human resources were distributed as follows: $15.88 \%$, medical staff; $47.83 \%$, nursing staff; and $36.29 \%$, management and services staff.

We used intentional sampling, including nurses from different inpatient units of the hospital. They were approached at their work places during different shifts by the main researcher. The final sample comprised 21 nurses: 18 women and three men, who voluntarily agreed to participate in the study. This number was sufficient to guarantee data saturation, heterogeneity, reliability and variability. ${ }^{18}$ In the drafting of the final article, participants were all identified using the male gender in order to guarantee anonymity. Nurses who worked in rotating shifts in the hospital refused to participate. We excluded nurses who had been working in the hospital for less than six months, for we considered that they could not provide us with reliable information on the topic of our research.

Data collection took place between the months of April and June of 2010, through indepth interviews based on open-ended questions, for we believed this would be the best way for obtaining all the details about the participant's experience regarding the phenomenon we intended to study. We also utilized field records made at the end of each interview, which ended up being greatly useful in our data analysis.

The main researcher was responsible for conducting the interviews, asking the following questions: How do organizational problems affect your relationships and your work life? What skills do you use to solve them and what challenges do you encounter in this process? The interviews lasted approximately 70 minutes, and were recorded using a digital recorder. Among them, four were conducted in the Nursing School, six in the participant's home and eleven in the researcher's home, according to the participant's preference. Before conducting the interviews, participants were informed about our objectives and that the data were confidential. We also presented them with the possibility of voluntarily leaving the study at any time and we gave them consent forms to sign as a sign of respect for the participants and their autonomous decisions.

Data were analyzed using reflexive thinking throughout the entire process, following the steps set forth by Morse and Field: ${ }^{19}$ comprehending, synthesizing, theorizing and recontextualizing. This process encompassed socio-cultural constructs and analyzed how interpersonal work relationships are affected by organizational problems and their management. We also investigated what skills are used by nurses when communicating these problems to their superiors or attempting to solve them with their coworkers, giving meaning to phenomena in an individualized manner.

After data collection, we transcribed the interviews and read them line-by-line, extracting the most significant enunciations that would later on be grouped into categories.

We conducted a deductive coding process based on the main themes found and selected from the discourses (units of meaning), establishing thematic blocks and subthemes. A map of the results was then built and structured into three sections: themes specific to the categories, significant descriptions of these categories, and units of meaning attributed to each description.

Lastly, the interpretations ${ }^{20}$ made by the nurses with respect to the phenomenon of our study were generated with no manipulation of the data by the researchers. For the most part, the information was processed manually.

The quality of the data and results of our research were guaranteed by following the procedures recommended by Lincoln and Guba: ${ }^{21}$ reliability (the ability of reproducing results), credibility (authenticity of results), transferability (generalizability) and confirmability of results (through the researcher's reflection). Thus, our data are transferable to similar sociodemographic and sociocultural contexts. ${ }^{22}$

The research proposal was approved by the hospital's Healthcare Research Unit, on April 27 ${ }^{\text {th }}$, 2010. At all times we based our research on fundamental ethical principles and on the requisites put forth by Emmanuel. ${ }^{19}$

\section{RESULTS}

Based on the data content analysis we coded the following themes:

\section{How organizational problems affect relationships}

Our intent was to investigate how organizational problems affect work relationships. In this sense, most of our interviewees indicated that the 
units' poor organization and management translates into poor relationships:

[...] the general feeling that nursing workers have here is that of waiting for three p.m. or ten p.m. so that they can go home (I21).

this has been allowed since the beginning, and so they have gotten used to this form of working. [...] the logical thing to do would be for the two of us to reach an agreement, but that's not what happens (I01).

On the other hand, on occasions when professionals have tried to express these problems to their managers, they were met with unappreciative responses that negatively influenced subsequent inter-staff relationships:

[...] we had a couple of meetings with the manager that were a catastrophe. Not only did we not get anything out of them, we also distanced ourselves from each other (I15).

Others mentioned that when work is conducted within a pre-established order, interpersonal relationships are more easy-going and long-lasting:

work in the afternoon is more easy-going. That's when relationships with doctors are at their best, and thanks to this relationship, sometimes the morning relationship is improved a bit (I08).

\section{Work plan}

This theme helped us comprehend the importance of planned work procedures for nurses in inpatient units. Such planning is of utmost importance for reaching the unit's goals, which in turn requires the commitment of all professionals involved:

We have told the doctors that the disorganization when visiting patients bothers us, but they didn't care, they have their own interests. They do not care about the work of others (I12).

Through their discourse, interviewees mentioned motivation, training and information, as well as the crucial importance of having the appropriate number of nursing staff according to demands for developing positive work relations:

It's very difficult because there isn't enough time. Perhaps the problem is that there are not enough of us, as usual (I08).

sometimes in the summer, students come over before beginning their contracts, of their own initiative, in order to get to know the unit. However, this depends on each person, all I know is we must not get discouraged (I10).

\section{Clearly defined roles}

It is greatly important for nurses to have clearly defined roles with respect to the different professionals that work in the hospital. Most interviewees believed that each professional must be aware of what activities correspond to their role, and respect and accept those of others:

they tell us how nice and good we are. [...] if you carry out your role, but if you don't, they say: 'here you go, when you finish I'll come back.' Then you're no longer good because you weren't there to do what they wanted. We always have to show them (I01).

[...] our supervisors still have a non-nursing mentality or they understand nursing from another point of view (I12).

Here we must point out the scarce scientific production up to the present regarding the influence of poorly defined professional roles on hospital work organization and work relationships. Thus, we are limited in comparing our results with those of other studies.

\section{Communication in the disorganization}

This category analyzed the importance of the proper use of communication skills for expressing organizational problems and solving them. Participants considered that lack of communication affects the doctor-patient-nurse triangle, being that the latter is most greatly affected.

I realized that nobody had told me anything and I see this patient coming up to me in the corridor all dressed and with the IV still in his arm (I08).

The supervisor should be the one to put a stop to this situation, for it has been going on for years with the majority of the older doctors and it's hard to change [...]. He should be the one to say: 'no, this is how nursing work will be organized' (I09).

\section{Feelings about disorganization}

Under this category, we identified the feelings that emerge in nursing professionals regarding organizational problems and their management. In this sense, we found that some nurses feel at ease with a certain type of organization, while others in the same work place are dissatisfied. Such feelings expressed by the interviewees certainly influence the relationships they establish in the work place:

I feel abused with this disorganization [...]. There are people who have resigned to how things are, people 
who have been here for 20 years, and they see no problem with this way of working (I12).

On the other hand, there are those who feel like a "factory" and others who cannot see any solutions for their work situation:

they treat us as if we were a factory, we do everything for everyone. [...] this is also a chain, but each class must know what they have to do (I09).

as the years go by, I believe people's characters change, you feel that they don't care about you anywhere and that nobody supports you, when trying to solve certain things... (I21).

In light of the data obtained, we believe it would benefit the institution of our study to take into consideration the suggestions made by the participants and researchers for its improvement, in order to achieve the objective set forth by this study (Table 1 ).

\section{Table 1 - Suggestions for improvement made by nurses and researchers}

\begin{tabular}{|l|l|}
\hline \multicolumn{1}{|c|}{ Interviewees' suggestions for improvement } & \multicolumn{1}{|c|}{ Researchers' suggestions for improvement } \\
\hline $\begin{array}{l}\text { Have the management staff (supervisors and chiefs of service) } \\
\text { sit down to discuss and listen to the feelings of the nursing staff } \\
\text { regarding certain actions of the medical staff. Work on the orga- } \\
\text { nizational formats that prevent amicable interpersonal relation- } \\
\text { ships. }\end{array}$ & $\begin{array}{l}\text { Establish specific and continuous training actions } \\
\text { that provide nursing professionals with attitudes } \\
\text { such as empathy, authenticity and unconditional } \\
\text { acceptance; as well as active listening skills, proper } \\
\text { use of feedback and problem-solving methods. }\end{array}$ \\
$\begin{array}{l}\text { Encourage communication and teamwork, basing work on con- } \\
\text { sensual protocols and clearly defining and respecting the activi- } \\
\text { ties of each professional role. }\end{array}$ & $\begin{array}{l}\text { Develop, invest in and maintain teamwork follow- } \\
\text { ing the guidelines established in the new concept } \\
\text { of work for the 21 st century (participatory manage- } \\
\text { ment, collaborative work...). }\end{array}$ \\
$\begin{array}{l}\text { Attempt to work in an organized fashion and restructure work } \\
\text { on many levels: changing staff, establishing rotatory shifts for } \\
\text { all healthcare professionals, changing work and management } \\
\text { methods. }\end{array}$ & $\begin{array}{l}\text { Enhance assertive communication between work- } \\
\text { ers and managers in order to identify areas for } \\
\text { improvement, planning and carrying out organi- } \\
\text { zational changes together. }\end{array}$ \\
$\begin{array}{l}\text { Establish adequate and effective unit organization: always re- } \\
\text { specting the schedule for each activity, communicating to super- } \\
\text { visors the problems that affect nurses and seeking out solutions. }\end{array}$ & \\
$\begin{array}{l}\text { Organize work in each service according to the number of pro- } \\
\text { fessionals who work in each shift and the goals set forth. As far } \\
\text { as possible, all professionals must be aware of and embrace these } \\
\text { goals. }\end{array}$ & \\
\hline
\end{tabular}

\section{DISCUSSION}

When discussing the influence of work organization on the interpersonal relationship of workers, we can objectify how organizational disorder affects interpersonal relationships among workers. Some professionals indicate that the lack of order in their work results in relational confusion, even if there is a previously established work plan in the unit. These are characteristics proper of bureaucratic and structured organizational cultures, as is the case of the hospital of our study. This reality is distant from that of healthier or more horizontal forms of organization, which promote the well-being of its members: where each member has confidence in their work and that of their co-workers; where interpersonal relationships are harmonious; ${ }^{23}$ and where collaborative efforts are made to maximize workers' well-being and productivity. ${ }^{24-25}$
This effect of organizational disorder on interpersonal relationships found in our study also happens when it is assumed that everybody is aware and familiar with certain work procedures. In truth, they are customs that not every professional is aware of and they present challenges for fluidity in relationships (for example, schedule for patient visitation, review of clinical history, etc.). In light of this, other studies have demonstrated the need for developing participatory organizational management that includes workers in the process of change and improvement of the work environment, especially regarding demands and control over work. ${ }^{7}$

Our participants delegate the responsibility of reporting problems to the nursing supervisor to those they consider to be leaders, responsible for maintaining order and who mediate conflicts 
in the unit. Without these mediators, it would be very difficult for nurses to address their superiors, due to poor listening and lack of interest displayed in improving the conditions that affect them. Participants also mentioned having difficulties when attempting to find solutions to organizational problems together with managers (nursing management, hospital manager) among them: they grow even more distant, or management decides the contrary of what was desired, worsening interpersonal relationships within services.

According to our participants and the evidence found in the literature, such lack of organization affects the nursing staff in particular, for it leads to work overload ${ }^{26}$ and makes them vulnerable to making more mistakes while carrying out their work. These mistakes regard not only to treatment errors, ${ }^{27}$ but also unwelcome surprises ("a patient who has been discharged goes home still with his IV in place"), consequences of the lack of communication between professionals. In fact, one of the current challenges of healthcare managers is to plan training policies and establish recognition policies (incentives) in their institutions. ${ }^{1}$

In this sense, our participants believe that planning work means organizing it according to the available time and staff, as well as making pertinent changes to the institution's organizational policy. ${ }^{28}$ The institution must keep in mind that in order to accomplish the goals established by management, the hospital must have enough staff members and they must be motivated, informed and trained. Management must also take into into consideration the quality of the care provided by professionals and received by patients. ${ }^{29-30}$ This reflection shared by most participants clashes with the current situation experienced by nursing professionals. They are overcome with demotivation and lack of interest in their work, which are possibly related to the issues mentioned above. Sánchez, Torres y Palacio $^{31}$ suggest that a possible solution for such problems lies in a horizontal institutional design, where nursing professionals display more satisfaction and motivation for their work, report conducting their work with autonomy and feel like a part of the organization.

On the other hand, professionals indicated the lack of clearly defined professional roles as part of the organizational problem that contributes to poor relationships. Thus, if each professional were aware of the activities pertaining to his/her role and that of others, nobody would be bothered by other people's work. Furthermore, clearly defined roles help reduce the stress felt by those professionals who take responsibility for the tasks of others, and the nursing staff would no longer feel like they are constantly having to prove their professional worth and credibility. Thus, their professional self-esteem would be enhanced.

Some nurses consider these circumstances that are part of the work place's daily life as "normal," because that is how the work routine has been since the beginning. Other nurses, on the other hand, are more critical and feel frustrated ${ }^{8}$ about being part of a static organization that allows for little change, despite the advances of science, technology and social and professional needs. This is the case of the participants that reported feeling like a "factory." They experience their professional activity as arriving at their work post, carrying our their tasks according to the organizational guidelines that organize their unit, trying to get what they can out of work, complaining as little as possible so that nobody labels them as "protestors" and going home.

This study was carried out in a specific context (a hospital in a small town) and with a limited number of participants, facts that constitute possible limitations. Thus, we recommend that it be replicated in other Spanish cities, as well as in other countries, taking into consideration the cultural and social aspects of the different participants. We also recommend further intervention studies to deepen the knowledge obtained here and evaluate the effectiveness of the suggestions described in this article.

\section{FINAL CONSIDERATIONS}

In conclusion, our results demonstrate that in most of the hospital's units, professionals experience relational chaos due to the lack of work order and organization. This situation is characteristic of organizations that possess bureaucratic and structured guidelines. On the other hand, services that rely on organizational order and control, in which communication among all members is encouraged, enjoy friendly and satisfactory interpersonal work relationships. In the reality of this study, nursing professionals reported feelings of impotence before such organizational disorder and the way it is managed by the administration. This translates into unmotivated professionals with no inclination to achieve collective goals or to help make working relations easier, and who do not develop skills such as empathy in order to report non-conformances and improve work relationships. 


\section{REFERENCES}

1. Garlet ER, Dias da Silva MA, Guedes JL, Quintana G. Organização do trabalho de uma equipe de saúde no atendimento ao usuário em situações de urgência e emergencia. Texto Contexto Enferm. 2009 Abr-Jun; 18(2):266-72.

2. Cibanal L, Arce MC, Carballal MC. Técnicas de comunicación y relación de ayuda en Ciencias de la Salud. $2^{\mathrm{a}}$ ed. Madrid (ES): Elsevier España; 2010.

3. Rickard G, Lenthall S, Dollard M, Opie T, Knight S, Dunn S, et al. Organizational intervention to reduce occupational stress and turnover in hospital nurses in the Northern Territory, Australia. Collegian. 2012 Jul; 19(4):211-21.

4. McCabe TJ, Sambrook S. The antecedents, attributes and consequences of trust among nurses and nurse managers: A concept analysis. Int J Nurs Stud. 2013 Oct.

5. Fawzi R, Hasan F, Fawzi A. The moderating effect of social support on the stress-satisfaction relationship among Jordanian hospital nurses. J Nurs Manage. 2009 May; 17(7):870-8.

6. Scarnera P, Bosco A, Soleti E, Lancioni G. Preventing burnout in mental health workers at interpersonal level: an Italian pilot study. Community Ment Health J. 2009 Ene; (45):222-7.

7. Cardoso AL, Solange T, Camponogara S, Harter R, Petri J, Cassol F, et al. Condições de trabalho e características sóciodemográficas relacionadas à presença de distúrbios psíquicos menores em trabalhadores de enfermagem. Texto Contexto Enferm. 2009 Abr-Jun; 18(2):215-23.

8. Menenghini F, Aparecida A, Lautert L. Fatores ocupacionais associados aos componentes da síndrome de burnout em trabalhadores de enfermagem. Texto Contexto Enferm. 2011 AbrJun; 20(2):225-33.

9. Manzano G. Síndrome de burnout y riesgos psicosociales en personal de enfermería. Inform Psicológica. 2008; 91(92):23-31.

10. Trovo MM, Paes MJ. O conhecimento de estratégias de comunicação no atendimento à dimensão emocional em cuidados paliativos. Texto Contexto Enferm. 2012 Jan-Mar; 21(1):121-9.

11. Sherman M. The value of direct care nurses with new health care strategies. Nurs Womens Health. 2012 Dec; 16(6):501-4.

12. Gómez G, Moore P, Araos E. Learning doctor-patient communication: does co-teaching help? Rev Med Chile. 2012 Mar; 140(3):396-403.

13. Wloszczak A, Jarosz MJ. Professional communication competences of nurses. Annals Agricult Environ Med. 2012; 19(3):601-8.

14. Scherlowski HM, Chaves MY, Gomes V, De Souza MA, Henriques F. Organização do trabalho de enfermagem na atenção básica: uma questão para a saúde do trabalhador. Texto Contexto Enferm. 2009 Abr-Jun; 18(2):206-14.

15. García C, Ogando B. Comunicación eficaz para profesionales de la salud. Enferm Cient. 2005: 31-9.

16. De la Cuesta C. El investigador como instrumento flexible de la indagación. Int J Qual Methods. 2003; 2(4):25-38.

17. Flick, U. Introducción a la investigación cualitativa. $2^{\mathrm{a}}$ ed. Madrid (ES): Morata, 2007.

18. Polit D, Hungler B. Investigación científica en ciencias de la salud. $6^{\text {a }}$ ed. México: MC Graw Hill; 2000.

19. Morse JM, Field PA. Qualitative research methods for health professionals. $2^{\mathrm{a}}$ ed. Thousand Oaks (US): Sage; 1995.

20. Ruíz, JI. La investigación cualitativa. In: Metodología de la investigación cualitativa. $2^{\mathrm{a}}$ ed. Bilbao (ES): Universidad de Deusto; 1999. p. 11-40.

21. Lincoln YS, Guba EG. Naturalistic inquiry. Newbury Park (CA): Sage; 1985.

22. Morse JM. Asuntos críticos en los métodos de investigación cualitativa. Alicante (EP): Publicaciones de la Universidad de Alicante, Monografías, 2005.

23. Castro A. Percepción del clima de aceptación de la diversidad en las organizaciones. Bol Psicol. 2010 Mar; (98):41-53.

24. Grau E, Gil PR, García JA, Figueiredo H. Efectos de los conflictos interpersonales sobre el desarrollo del Síndrome de Quemarse por el Trabajo (Burnout) y su influencia sobre la salud: un estudio longitudinal en enfermería. Ciencia Trabajo. 2009 Abr-Jun; 11(32):72-9.

25. Cominetti L, Lorenza T, Decorte R, Felisi N, Matta E, Actis MV, Carone R, Gregorino S, Valerio, D. Evaluation of staff's job satisfaction in the spiral cord unit in Italy. Open Nurs J. 2013 Apr 5; 7:49-56.

26. Lima T, Pires DEP. Implicações dos modelos assistenciais da atenção básica. nas cargas de trabalho dos profissionais de saúde. Texto Contexto Enferm [online]. 2013 Ene-Mar [acesso 2013 Jun 20]; 22(1):36-42. Disponível em www.index-f.com/ textocontexto/2013pdf/22-036.pdf

27. Nascimento CC, Toffoletto MC, Gonçalves LA, Freitas Wd, Padilha KG. Indicators of healthcare results: analysis of adverse events during hospital stays. Rev Latino-Am Enferm. 2008 Ago; 16(4):74651.

28. OroJ,Matos E. Possibilidades e limites de organização do trabalho de enfermagem no modelo de cuidados integrais em instituição hospitalar. Texto Contexto Enferm [online]. 2013 Abr-Jun [acesso 2013 Jun 22]; 22(2):500-8. Disponível em www.index-f.com/ textocontexto/2013pdf/22-500.pdf

29. Fuentelsaz C, Moreno T, López D, Gómez T, González E. Percepción del entorno laboral de las enfermeras españolas en los hospitales del Sistema 
Nacional de Salud. Proyecto RN4CAST-España Enferm Clin. 2012 Sep-Oct; 22(5):261-8.

30. Sermeus W, Aiken LH, Van den Heede K, Rafferty AM, Griffiths P, Moreno MT, et al. Nurse forecasting in Europe (RN4CAST): rationales, design and methodology. BMC Nursing. 2011 Abr; 10:6.

31. Sánchez S, Torres MD, Palacio R. Grado de satisfacción de las enfermeras del área quirúrgica de un hospital de nueva apertura en la comunidad de Madrid. ENE Rev Enferm. 2010 Abr; 4(1):8-19. 